\title{
PENINGKATAN PRESTASI BELAJAR BAHASA INGGRIS MATERI IF CONDITIONAL TYPE 1 MELALUI MODEL PEMBELAJARAN GROUP INVESTIGATION
}

\author{
SRI HARNINGSIH \\ SMAN 1 Pemalang \\ Email : harningsih1604@gmail.com
}

\begin{abstract}
ABSTRAK
Tujuan penelitian ini adalah untuk mengetahui apakah dengan Model Pembelajaran Group Investigation dapat meningkatkan prestasi belajar Bahasa Inggris siswa kelas XI MIPA-1 semester gasal Sekolah Menengah Atas Negeri 1 Pemalang tahun pelajaran 2021/2022.Subjek penelitian tindakan kelas ini adalah siswa kelas XI MIPA-1 Sekolah Menengah Atas Negeri 1 Pemalang pada Semester Gasal Tahun Pelajaran 2021/2022. Variabel penelitian ini terdiri dari variabel siswa dan variabel guru. Variabel siswa dengan melihat kemampuan siswa dalam menyelesaikan soal, sedangkan variabel guru yaitu dengan melihat cara guru membuat rencana pembelajaran dan bagaimana pelaksanaannya di dalam kelas.Penelitian dilakukan dengan tiga siklus dan masing-masing siklus terdiri atas empat tahapan, yakni: perencanaan, pelaksanaan, observasi dan refleksi. Indikator keberhasilan ditetapkan bila minimal terdapat $75 \%$ siswa mencapai ketuntasan belajar setelah diterapkan Model Group Investigation. Dari hasil peneltian tindakan ini diperoleh informasi bahwa ada peningkatan prestasi belajara Bahasa Inggris siswa kelas XI MIPA-1 Sekolah Menengah Atas Negeri 1 Pemalang pada Semester Gasal Tahun Pelajaran 2021/2022. Peningkatan itu ditunjukkan dengan: (1) rata-rata prestasi belajar siswa pada siklus I adalah 7,14; pada siklu siklus II adalah 7,44; dan pada siklus III adalah 8,44 (2) ketuntasan belajar siswa pada siklus I adalah 17 siswa atau 47,22\%; siklus II adalah 22 siswa atau 72,22\%; dan pada siklus III adalah 36 siswa atau 100\%; (3) ketuntasan belajar klasikal pada siklus I adalah 47,22\%; siklus II adalah $72,22 \%$; dan pada siklus III mencapai $100,00 \%$. Ini berarti prestasi belajar Bahasa Inggris siswa mengalami peningkatan pada setiap siklus dan sudah melampaui indikator yang telah ditentukan. Disamping itu juga ada peningkatan aktivitas siswa selama proses pembelajaran, baik secara individu maupun secara kelompok.Berdasarkan hasil penyebaran angket untuk siswa menunjukkan bahwa respon siswa kelas XI MIPA-1 Sekolah Menengah Atas Negeri 1 Pemalang pada Semester Gasal Tahun Pelajaran 2021/2022 terhadap pelaksanaan Model Group Investigation mencapai 83,14\% menyatakan sangat setuju atau dalam kategori tinggi.
\end{abstract}

Kata kunci: group investigation, ptk model gi

\section{ABSTRACT}

The purpose of this research is to know whether Learning Model of Group Investigation can increase the students'achievement of XI MIPA 1 SMAN 1 Pemalang on the third semester in academic year 2021/2022. The subject of this classroom action research is the students of XI MIPA 1 of SMAN 1 Pemalang on third semester in academic year 2021/2022. The research variable consists of students and teacher variable. The students variable can be seen on their ability on solving the questions, while the teacher variable is seen by considering the way she plan the lesson and she conducts the classroom activity. This research is conducted in 3 cycles and each cycle consists of 4 steps, those are planning, conducting, observing and rfeflecting. The indicators of its success is measured when at least $75 \%$ students achieve the learning completion after the implementation of Group Investigation Model. From the result of this classroom action research, it is gained that the students'achievement in English especially in 'If Conditional' can increase significantly. The increasing of the achievement can be shown by: 1) The average of students'achievement on cycle I is 7.14, on cycle II is 7.44 , and on cycle III is 8.44 , and then students learning completion on cycle I is 17 students or $47.22 \%$, on cycle II is 22 students or $72,22 \%$, and on cycle III is 36 students or $100 \%$, and finally the classical 
learning completion on cycle I is $47.22 \%$, Cycle II is $72.22 \%$, and on Cycle III achieving $100 \%$. It means that students achievement on English 'If Conditional' can increase in every cycle and it has completed indicator that has been determined. Beside that, there is an increasing students activity during the teaching learning process, both individually and classically. Based on the distribution of questionnaire for the students, it can be seen that students' respond of XI MIPA 1 SMA Negeri 1 Pemalang on the third Semester in academic year 2021/2022 toward the implementation of Group Investigation Model achieving $83.14 \%$ state that they extremely agree or in a high category.

Key words: group investigation, classroom action research model gi

\section{PENDAHULUAN}

Bahasa Inggris memiliki peranan yang penting dalam upaya untuk berkomunikasi dan penjembatan dengan pihak dunia luar. Bahasa merupakan kunci penentu menuju keberhasilan dan memiliki peran sentral, khususnya dalam perkembangan intelektual, sosial, dan emosional seseorang dan dalam mempelajari semua bidang studi. Bahasa diharapkan bisa membantu seseorang dalam hal ini adalah peserta didik untuk mengenal dirinya, budayanya dan budaya orang lain, mengemukakan gagasan dan perasaan, berpartisipasi dalam masyarakat yang menggunakan bahasa tersebut, menemukan serta menggunakan kemampuan-kemampuan analitis dan imaginative dalam dirinya.

Dalam proses pembelajaran, guru sangat penting peranannya, peran guru yang cukup dominan seperti memberikan contoh bagaimana bahasa inggris yang baik (model); memberikan motivasi; agar siswa senang belajar bahasa Inggris (motivator); memfasilitasi siswa dalam belajar bahasa Inggris (fasilitator); menjadi partner dalam kegiatan belajar; mengevaluasi bahasa Inggris siswa (evaluator); dan memantau penggunaan bahasa Inggris siswa (monitor). Peran-peran tersebut lahir sebagai akibat yang tak terhindarkan dari penyelenggaraan pembelajaran bahasa yang tepusat pada siswa. Tentunya temuan di lapangan memberi suatu kesimpulan bahwa peran yang ditunjukkan oleh seorang guru sangat sesuai dengan hakikat belajar bahasa yaitu untuk tujuan komunikatif dimana penekanan akhirnya adalah untuk berkomunikasi. Dengan demikian, kegiatan pembelajaran bahasa inggris yang baik diharapkan mampu memberikan kesempatan sebanyak-banyaknya kepada siswa untuk mengunakan bahasa tersebut dalam kegiatan berkomunikasi.

Kesulitan belajar yang dialami oleh siswa disebabkan oleh beberapa faktor antara lain metode dan pendekatan bahkan model yang digunakan oleh guru dalam menyampaikan materi pelajaran kurang tepat. Pengajaran hendaknya disesuaikan dengan situasi dan kondisi siswa. Pendekatan pembelajaran tradisional, yang hanya menjejali siswa dengan konsep dan fakta, sudah tidak sesuai lagi, bahkan tidak manusiawi. Dengan pendekatan tradisional aktivitas dan kreatifitas siswa tidak banyak tersentuh. Oleh karena itu diperlukan pendekatan pembelajaran yang melibatkan siswa secara intelektual dan emosional, sehingga siswa terlatih belajar secara aktif dan kreatif. Salah satu alternatif yang dapat dipilih yaitu menggunakan model pembelajaran kooperatif dengan teknik Group Investigation (GI).

Model pembelajaran kooperatif tipe Group Investigation (GI) dikembangkan oleh Shlomo Sharon dan Yael Sharon. Secara umum perencanaan pengorganisasian kelas dengan menggunakan teknik kooperatif GI adalah kelompok dibentuk oleh siswa itu sendiri dengan beranggotakan 2-6 orang, tiap kelompok bebas memilih subtopik dari keseluruhan unit materi (pokok bahasan) yang akan diajarkan, dan kemudian membuat atau menghasilkan laporan kelompok. Selanjutnya, setiap kelompok mempresentasikan atau memamerkan laporannya kepada seluruh kelas, untuk berbagi dan saling tukar informasi temuan mereka. Temuan strategi GI sebenarnya dilandasi oleh filosofi belajar John Dewey. Teknik kooperatif ini telah secara meluas digunakan dalam penelitian dan memperlihatkan kesuksesannya terutama untuk program-program pembelajaran dengan tugas-tugas spesifik (Rusman, 2011:220).

Apalagi disaat pandemi Covid 19, guru dituntut untuk mengorganisasikan kelas supaya menarik dan siswa dapat terlibat aktif dalam pembelajaran, tidak merasa jenuh karena hanya 
diberi tugas -tugas saja, tetapi dengan diterapkannya model pembelajaran kooperatif tipe group investigation siswa dapat berinteraksi aktif dengan guru dan juga teman-teman dalam kelompoknya baik melalui kelas maya dengan media google meet maupun pada saat pembelajarn Tatap Muka Terbatas.

Dari pengalaman peneliti anak-anak kelas XI MIPA 1 SMA Negeri 1 Pemalang tahun pelajaran 2021/2022 cenderung diam dan mendengarkan saja ketika diajar, mereka kurang responsif sehingga kelas terlihat sepi dan kurang menarik. Dari kondisi ini akhirnya peneliti mengambil inisiatif untuk menerapkan model pembelajaran kooperative learning dengan type Group investigation untuk menyampaikan materi "If Conditional" Type 1. Belajar bahasa Inggris harus ada ketrampilan yang dikuasai antara lain bisa membaca, menulis, berbicara dan juga mendengar. Dengan penerapan model Group Investigation ini anak anak pastilah akan terekspos untuk berkomunikasi di dalam grup tersebut walaupun dengan bahasa sederhana. Walaupun di era pandemi, sekolah peneliti tetap brorientasi pada mutu output maka dari itu proses pembelajran harus terlaksana dengan baik. Sesuai Surat Edaran Dinas Pendidikan dan Kebudayaan Propinsi Jawa Tengah pada bulan Agustus 2021 bahwa sekolah dapat melaksanakan kegiatan pembelajaran Tatap Muka Terbatas, maka peneliti bisa mengoptimalkan untuk menepakan tipe Group Investigation dalam pembelajran. Pembelajaran Jarak Jauh dan Pembelajaran Tatap Muka Terbatas menjadi blended learning di sekolah peneliti.

Pembelajaran Bahasa Inggris materi "If Conditional Type 1" menuntut para siswa untuk terampil dalam listening, speaking, reading and writing. Menurut Sudarwati dan Grace dalam buku Pathway to Englsih (2017:37) siswa-siswa harus mengausai kompetensi antara lain: mengidentifikasi bentuk kalimat If Conditional ( bentuk Tenses pada main clause dan sub clausenya), menulis kalimat dengan If Conditional, mengidentifikasi fungsi dan makna, menggunakan if Coditional dalam Dialog, menganalisis frase yang bisa menggantikan "If", mendemonstrasikan penggunaan "If Conditional Type 1" dalam mempromosikan produk. Untuk mencapai kompetensi tersebut siswa-siswa harus turut aktif terlibat dalam pembelajaran, sehingga type Group Investigation sangat baik untuk mengekspos kemampuan mereka.

Dari permasalahan keaktifan siswa dan prestasi belajar yang masih kurang, akhirnya peneliti mencoba menggunakan model pembelajaran Group Investigation untuk meningkatkan prestasi belajar siswa dan juga keaktifan mereka dalam pembelajaran baik Tatap muka maupun pembelajaran Jarak jauh.

\section{METODE PENELITIAN}

Penelitian ini adalah penelitian tindakan kelas dengan menggunakan 3 siklus dan merupakan penelitian deskrptive kualitatif. Subjek penelitian tindakan ini adalah siswa kelas XI MIPA-1 semester gasal Sekolah Menengah Atas Negeri 1 Pemalang tahun pelajaran 2021/2022, sebanyak 36 orang siswa. Variabel penelitian ini terdiri dari variabel siswa dan variabel guru. Variabel siswa dengan melihat kemampuan siswa dalam menyelesaikan soal, sedangkan variabel guru yaitu dengan melihat cara guru membuat rencana pembelajaran dan bagaimana pelaksanaannya di dalam kelas.

Penelitian dilakukan dengan tiga siklus dan masing-masing siklus terdiri atas empat tahapan, yakni: perencanaan, pelaksanaan, observasi dan refleksi. Indikator keberhasilan ditetapkan bila minimal terdapat $75 \%$ siswa mencapai ketuntasan belajar setelah diterapkan Model Group Investigation. Faktor yang hendak diteliti dalam penelitian ini adalah factor siswa yang meliputi keaktifan siswa dalam mengikuti proses belajar mengajar dan peningkatan hasil belajar siswa berupa kemampuan kognitif dalam memecahkan masalah setelah penerapan model pembelajaran kooperatif tipe Group Investigation (GI).yang kedua adalah factor guru yakni dengan kolaborator melihat cara guru merencanakan pembelajaran serta bagaimana pelaksanaannya di dalam kelas setelah menerapakan model pembelajaran kooperatif tipe Group Investigation (GI). 
Sebagai bentuk penelitian tindakan kelas, penelitian ini dilaksanakan dalam beberapa siklus. Masing-masing siklus terdiri dari perencanaan, pelaksanaan, pengamatan dan refleksi. Penelitian dilaksanakan pada siswa kelas XI MIPA-1 semester gasal Sekolah Menengah Atas Negeri 1 Pemalang tahun pelajaran 2021/2022. Hasil penelitian dititik-beratkan pada kemampuan siswa dalam mengerjakan soal materi pembelajaran sehingga hasil belajar dan ketuntasan belajar meningkat.

Langkah-langkah dalam penelitian ini ditunjukkan pada gambar siklus sebagai berikut:

Siklus Penelitian Tindakan

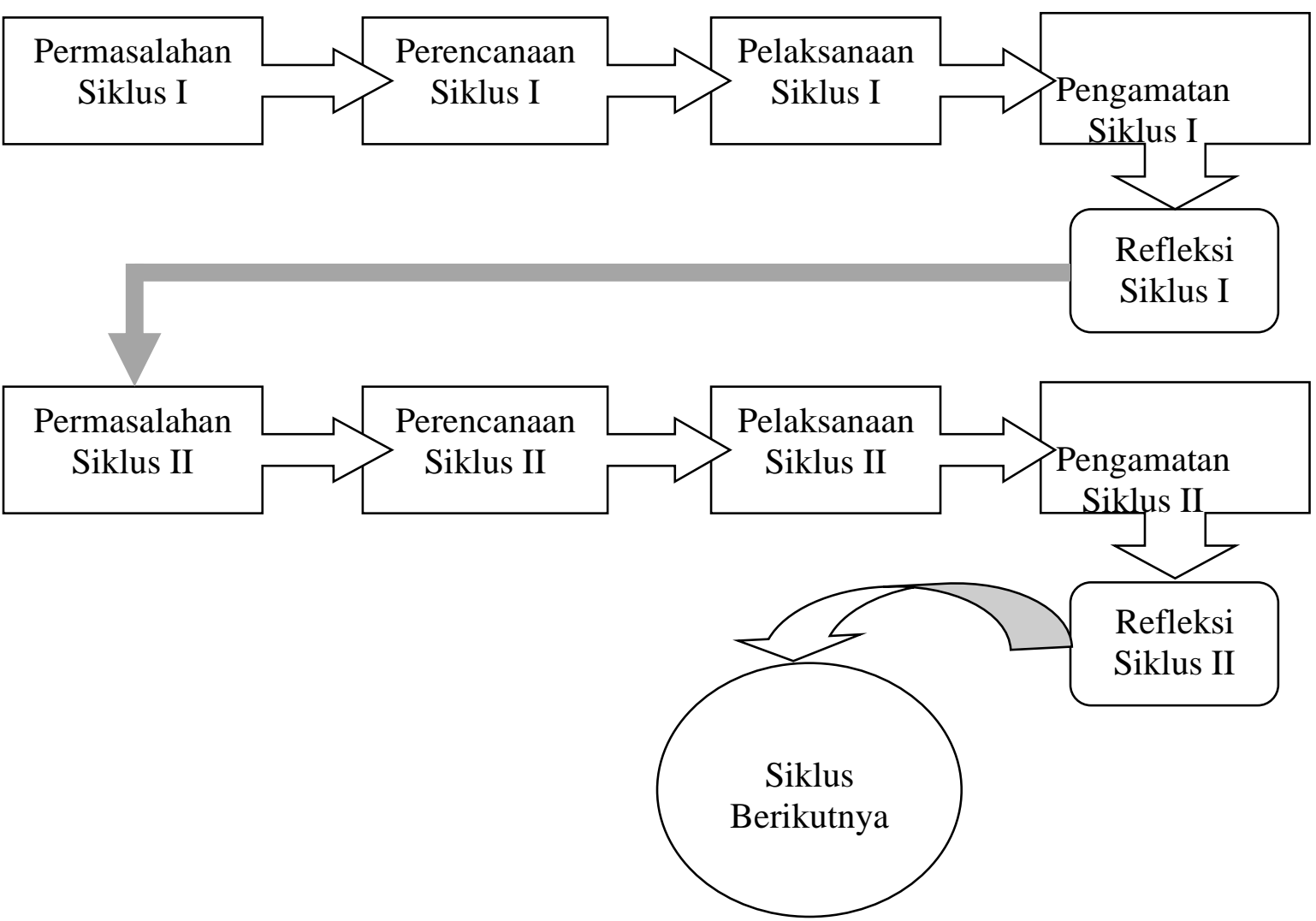

Gambar 1. Siklus Penelitian Tindakan

Alur dalam penelitian tindakan kelas ini terdiri atas 4 rangkaian kegiatan yang dilakukan dalam siklus berulang. Empat kegiatan utama yang ada pada setiap siklus yaitu perencanaan, tindakan, pengamatan dan refleksi.

\section{HASIL DAN PEMBAHASAN}

Hasil penelitian digambarkan dengan table yang menerangkan tentang keaktifan siswa dan peningkatan prestasi berdasarkan hasil evaluasi dalam 3 siklus.

Tabel 1. Keaktifan Siswa dalam Kelompok Siklus I

\begin{tabular}{|c|c|l|c|c|c|}
\hline \multicolumn{5}{|c|}{ KEAKTIFAN SISWA DALAM KELOMPOK SIKLUS I } \\
\hline No & \multicolumn{1}{|c|}{ Aktivitas Siswa } & Skor & $\%$ & Ket \\
\hline 1 & A. & Memperhatikan penjelasan guru & 72 & $50 \%$ & Cukup \\
\hline 2 & B. & Kerja sama dalam kelompok & 71 & $49 \%$ & Cukup \\
\hline 3 & C. & Bertanya antar siswa dan guru & 71 & $49 \%$ & Cukup \\
\hline 4 & D. & Keaktifan Menyelesaikan soal & 72 & $50 \%$ & Cukup \\
\hline
\end{tabular}




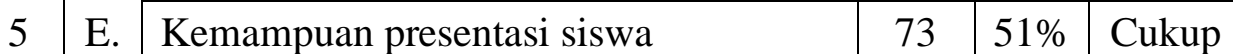

Dan secara grafis dapat dapat ditunjukkan pada gambar berikut:

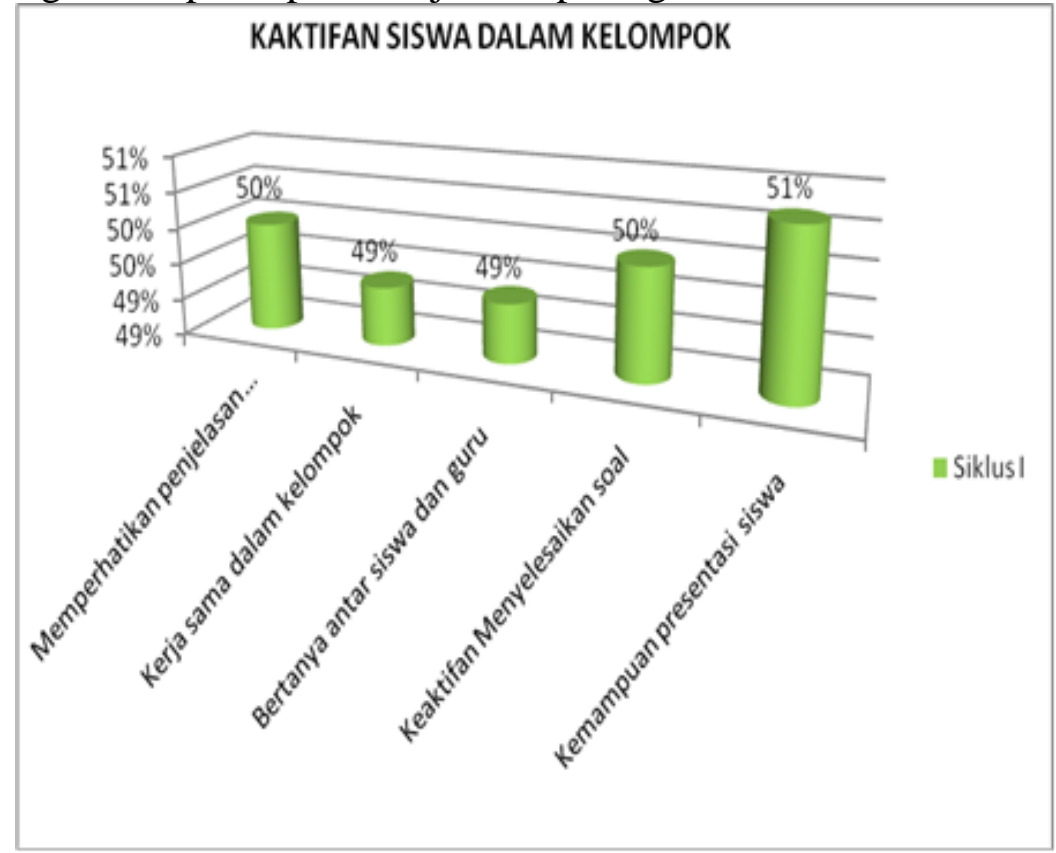

Gambar 2. Grafik Keaktifan siswa dalam kelompok

Keaktifan siswa pada siklus I dalam mengikuti kegiatan belajar mengajar dengan menggunakan pembelajaran kooperatif model Group Investigation (GI) masih dalam kategori “rendah", diperoleh skor 16 dari skor maksimal 30 dengan prosentase 53,33\%.

Hasil pengamatan terhadap kinerja/performace guru padasiklus I diperoleh skor 20 atau 51,28\% dari skor maksimal 39 dengan criteria pembelajaran "kurang" dalam menyampaikan materi, tetapi awal pelajaran kurang dapat memotivasi siswa sehingga dalam proses pembelajaran keaktifan siswa masih kurang.

Pengamatan hasil uji kompetensi/evaluasi siklus I diperoleh hasil sebagai berikut:

Tabel 2. Hasil Evaluasi Siklus I

\begin{tabular}{|l|l|c|}
\hline No. & \multicolumn{1}{|c|}{ Hasil Evaluasi } & Siklusi I \\
\hline 1. & Rata-rata & 7,14 \\
\hline 2. & Nilai tertinggi & 8,00 \\
\hline 3. & Nilai terendah & 5,60 \\
\hline 4. & Siswa tuntas & 17,00 \\
\hline 5. & Siswa tidak tuntas & 19,00 \\
\hline
\end{tabular}

Siswa yang tuntas baru 17 orang atau 47,22\%, karena prosentase ketuntasan belajar klasikal baru mencapai $47,22 \%$, maka belum memenuhi hasil yang diharapkan dari indicator ketuntasn/keberhasilan.

Dari pengamatan yang dilakukan terhadap aktivitas siswa dalam kelompok pada siklus II diperoleh hasil sebagai berikut:

Tabel 3.Keaktifan Siswa dalam Kelompok Siklus II

\begin{tabular}{|c|c|l|c|c|c|}
\hline \multicolumn{5}{|c|}{ KEAKTIFAN SISWA DALAM KELOMPOK SIKLUS II } \\
\hline No & \multicolumn{1}{|c|}{ Aktivitas Siswa } & Skor & $\%$ & Ket \\
\hline 1 & A. & Memperhatikan penjelasan guru & 105 & $73 \%$ & Sedang \\
\hline 2 & B. & Kerja sama dalam kelompok & 109 & $76 \%$ & Sedang \\
\hline
\end{tabular}




\begin{tabular}{|l|l|l|c|c|c|}
\cline { 3 - 6 } 3 & C. & Bertanya antar siswa dan guru & 106 & $74 \%$ & Sedang \\
\hline 4 & D. & Keaktifan Menyelesaikan soal & 108 & $75 \%$ & Sedang \\
\hline 5 & E. & Kemampuan presentasi siswa & 104 & $72 \%$ & Sedang \\
\hline
\end{tabular}

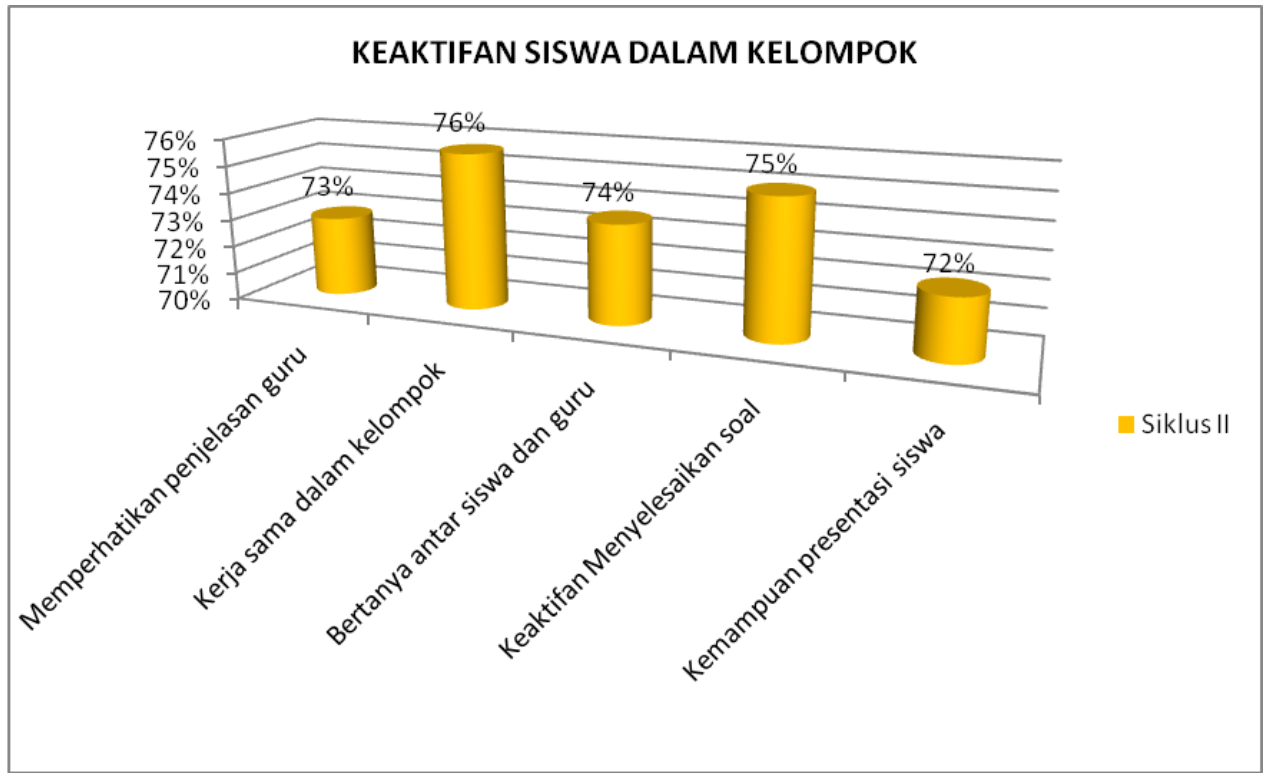

\section{Gambar 3. Grafik keaktifan siswa dalam kelompok Siklus II}

Keaktivan siswa pada siklus II dalam mengikuti kegiatan belajar mengajar dengan menggunakan pembelajaran kooperatif model Group Investigation (GI) sudah mengalami peningkatan, diperoleh skor 22 dariskormaksimal 30 dengan prosentase 73,33\% pada kategori "sedang".

Hasil pengamatan terhadap kinerja/performance guru pada siklus II diperoleh skor 29 atau $74,36 \%$ dari skor maksimal 39 dengan kriteria pembelajaran "cukup".

Pengamatan hasil uji kompetensi/evaluasi siklusII diperoleh hasil sebagai berikut:

Tabel 4. Hasil Evaluasi Siklus II

\begin{tabular}{|l|l|c|}
\hline No. & \multicolumn{1}{|c|}{ Hasil Evaluasi } & Siklusi II \\
\hline 1. & Rata-rata & 7,44 \\
\hline 2. & Nilai tertinggi & 8,40 \\
\hline 3. & Nilai terendah & 5,60 \\
\hline 4. & Siswa tuntas & 26,00 \\
\hline 5. & Siswa tidak tuntas & 10,00 \\
\hline
\end{tabular}

Karena prosentase ketuntasan belajar klasikal baru mencapai $72,22 \%$, berarti belum mencapai indicator ketuntasan yang telah ditentukan, yaitu $75 \%$. Untuk itu perlu dilakukan tindakan lanjutan, yaitu siklus III.

Dari pengamatan yang dilakukan terhadap aktivitas siswa dalam kelompok pada siklus II diperoleh hasil sebagai berikut:

Tabel 5. Keaktifan Siswa dalam Kelompok Siklus III

\begin{tabular}{|c|c|l|c|c|c|}
\hline \multicolumn{5}{|c|}{ KEAKTIFAN SISWA DALAM KELOMPOK SIKLUS III } \\
\hline No & \multicolumn{2}{|c|}{ Aktivitas Siswa } & Skor & $\%$ & Ket \\
\hline 1 & A. & Memperhatikan penjelasan guru & 135 & $94 \%$ & Tinggi \\
\hline 2 & B. & Kerja sama dalam kelompok & 137 & $95 \%$ & Tinggi \\
\hline 3 & C. & Bertanya antar siswa dan guru & 134 & $93 \%$ & Tinggi \\
\hline
\end{tabular}




\begin{tabular}{|l|l|l|c|c|c|}
\cline { 2 - 6 } 4 & D. & Keaktifan Menyelesaikan soal & 129 & $90 \%$ & Tinggi \\
\hline 5 & E. & Kemampuan presentasi siswa & 134 & $93 \%$ & Tinggi \\
\hline
\end{tabular}

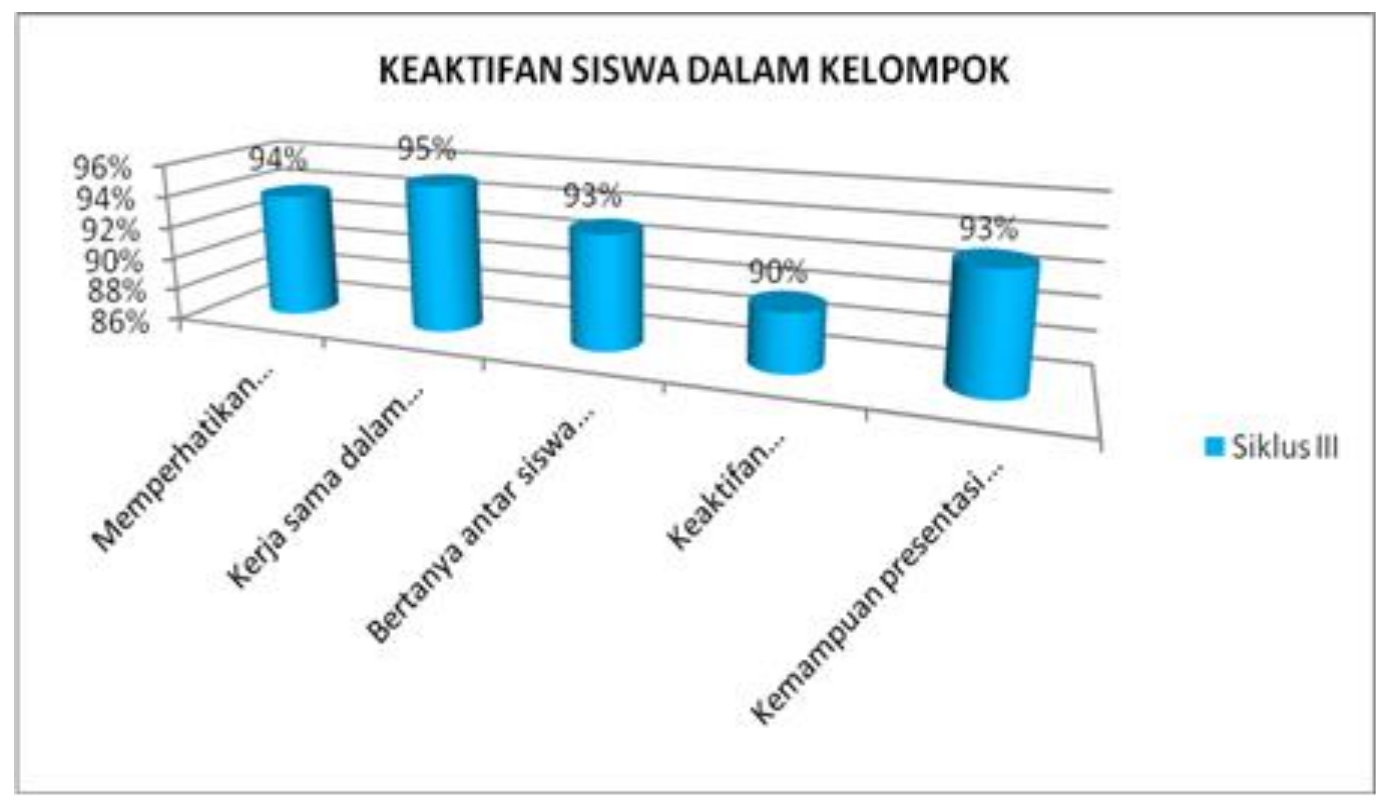

Gambar 4. Grafik keaktifan siswa dalam kelompok Siklus III

Keaktivan siswa pada siklus III dalam mengikuti kegiatan belajar mengajar dengan menggunakan pembelajaran kooperatif model Group Investigation (GI) sudah mengalami peningkatan, diperoleh skor 28 dari skor maksimal 30 dengan prosentase 93,33\% pada kategori "tinggi".

Hasil pengamatan terhadap kinerja/performance guru pada siklus III diperoleh skor 37 atau 94,87\% dari skor maksimal 39 dengan kriteria pembelajaran "baik”.

Pengamatan hasil uji kompetensi/evaluasi siklus III diperoleh hasil sebagai berikut:

Tabel 6. Hasil Evaluasi Siklus II

\begin{tabular}{|l|l|c|}
\hline No. & \multicolumn{1}{|c|}{ Hasil Evaluasi } & Siklusi II \\
\hline 1. & Rata-rata & 8,84 \\
\hline 2. & Nilai tertinggi & 10,00 \\
\hline 3. & Nilai terendah & 8,00 \\
\hline 4. & Siswa tuntas & 66,00 \\
\hline 5. & Siswa tidak tuntas & 0,00 \\
\hline
\end{tabular}

Karena prosentase ketuntasan belajar klasikal sudah mencapai $100 \%$, berarti sudah mencapai indikator ketuntasan yang telah ditentukan, yaitu $75 \%$. Untuk itu tidak perlu lagi dilakukan tindakan lanjutan.

\section{Perbandingan Siklus I, Siklus II dan Siklus III}

a. Keaktifan Siswa dalam Kelompok

Tabel 7. Keaktifan Siswa dalam Kelompok

\begin{tabular}{|c|c|l|c|c|c|c|}
\hline \multicolumn{7}{|c|}{ PERBANDINGAN KEAKTIFAN SISW A DALAM KELOMPOK } \\
\hline No & \multicolumn{2}{|c|}{ Aktivitas Siswa } & $\begin{array}{c}\text { Siklus } \\
\text { I }\end{array}$ & $\begin{array}{c}\text { Siklus } \\
\text { II }\end{array}$ & Siklus III & Keterangan \\
\hline 1 & A. & Memperhatikan penjelasan guru & $50 \%$ & $72,92 \%$ & $93,75 \%$ & Meningkat \\
\hline 2 & B. & Kerja sama dalam kelompok & $49 \%$ & $75,69 \%$ & $95,14 \%$ & Meningkat \\
\hline
\end{tabular}


LANGUAGE : Jurnal Inovasi Pendidikan Bahasa dan Sastra

Vol 1. No 2. November 2021, e-ISSN : 2807-1670 | p-ISSN : 2807-2316

\begin{tabular}{|l|l|l|l|l|l|l|}
3 & C. & Bertanya antar siswa dan guru & $49 \%$ & $73,61 \%$ & $93,06 \%$ & Meningkat \\
\hline 4 & D. & Keaktifan Menyelesaikan soal & $50 \%$ & $75,00 \%$ & $89,58 \%$ & Meningkat \\
\hline 5 & E. & Kemampuan presentasi siswa & $51 \%$ & $72,22 \%$ & $93,06 \%$ & Meningkat \\
\hline
\end{tabular}

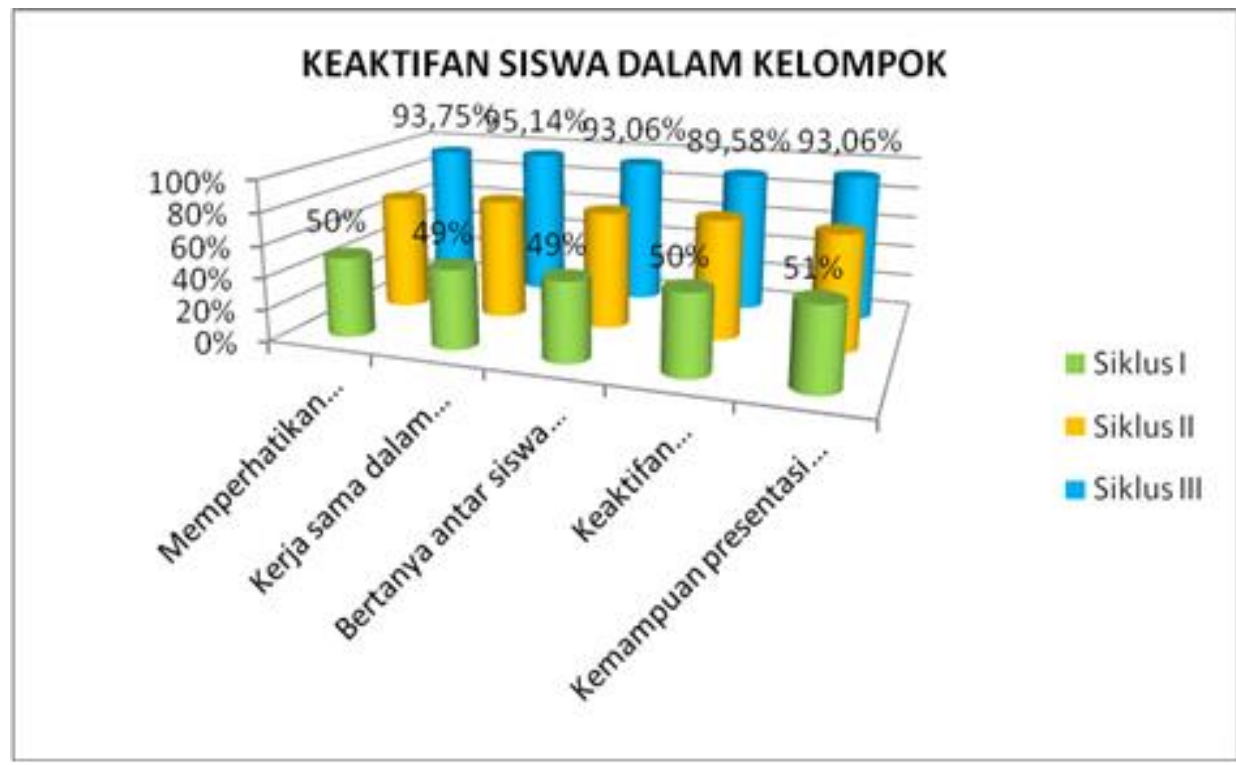

Gambar 5. Grafik perbandingan siswa dalam kelompok

Tabel 8. Perbandingan Komulatif Siklus I, Siklus II dan Siklus III TABEL KOMULATIF PERBANDINGAN SIKLUS I, II DAN III

\begin{tabular}{|c|l|c|c|c|}
\hline No & \multicolumn{1}{|c|}{ Indikator } & Siklus I & Siklus II & Siklus III \\
\hline 1 & Keaktifan siswa & $53 \%$ & $73 \%$ & $93 \%$ \\
\hline 2 & Keaktifan dalam kelompok & $50 \%$ & $74 \%$ & $93 \%$ \\
\hline 3 & Nilai rata-rata siswa & $49 \%$ & $74 \%$ & $93 \%$ \\
\hline 4 & Siswa tuntas & $47 \%$ & $72 \%$ & $100 \%$ \\
\hline 5 & Siswa tidak tuntas & $53 \%$ & $28 \%$ & $0 \%$ \\
\hline 6 & Ketuntasan klasikal & $47 \%$ & $72 \%$ & $100 \%$ \\
\hline 7 & Kinerja Guru & $51 \%$ & $74 \%$ & $95 \%$ \\
\hline 8 & Minat Siswa & \multicolumn{3}{|l}{$83,14 \%$} \\
\hline
\end{tabular}

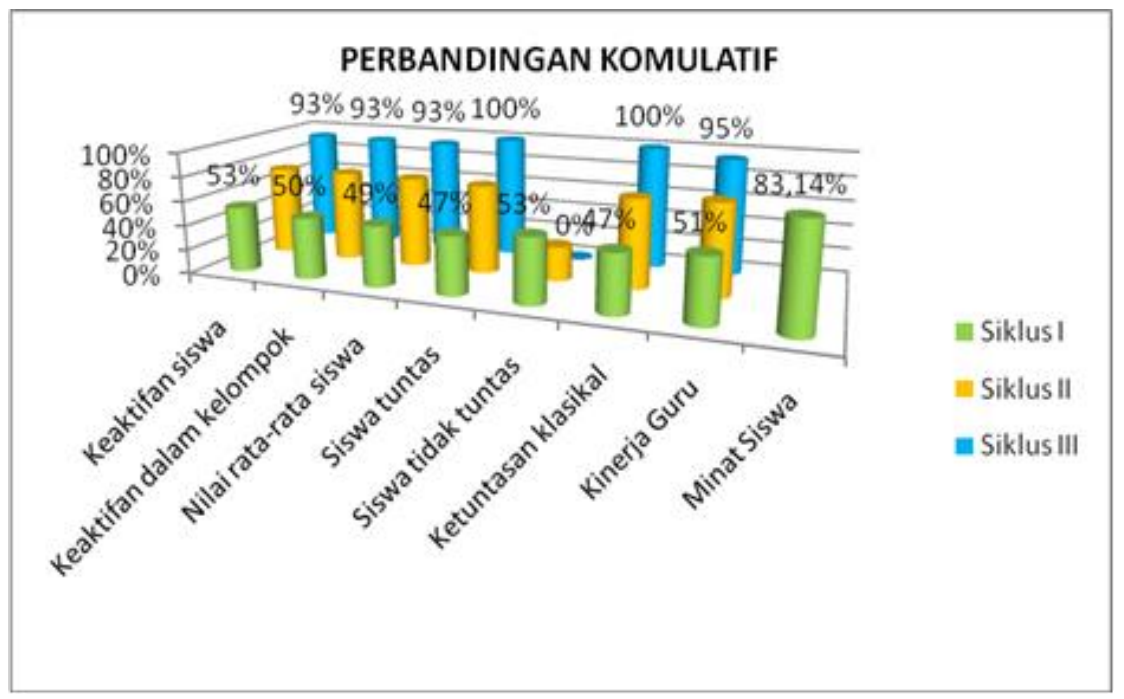

Gambar 6. Perbandingan Komulatif Siklus I, Siklus II dan Siklus III 


\section{Pembahasan}

Pembahasan hasil penelitian ini didasarkan pada hasil pengamatan dan dilanjutkan dengan refleksi siklus I, siklus II dan siklus III. Pada siklus I berdasarkan pengamatan yang dilakukan pada guru, menunjukkan bahwa guru kinerjanya selalu mengalami peningkatan pada setiap siklus. Dapat dilihat pada lembar hasil pengamatan kinerja/performance guru siklus I, menunjukkan skor yang diperoleh yaitu 20 atau 51,28\% dari skor maksimal 39, menunjukkan bahwa kinerja guru dalam kategori "kurang". Hasil pengamatan kinerja guru pada siklus II, diperoleh skor 29 atau 74,36\% dari skor maksimal 39, dengan kategori "cukup". Sedangakan pada siklus III, diperoleh skor 37 atau 94,87 dari skor maksimal 39, pada kategori "baik". Berdasarkan hasil tersebut membuktikan bahwa kinerja/performace guru selalu mengalami peningkatan dalam proses penelitian tindakan kelas ini.

Pengamatan kepada aktivitas siswa skor yang diperoleh dari lembar pengamatan aktivitas siswa siklus I, yaitu 13 atau 53,33\% dari skor maksimal 30 dan dalam kategori "rendah"; pada siklus II menunjukkan bahwa keaktifan siswa sedikit meningkat, diperoleh skor 22 atau 73,33\% dari skor maksimal 30 dan dalam kategori "sedang"; sedangkan pada siklus III, mengalami peningkatan lagi, diperoleh skor 28 atau 93,33\% dari skor maksimal, dengan kategori "tinggi".

Pengamatan pada hasil evaluasi pada siklus I dapat dilihat pada hasil uji kompetensi siklus I, yang menunjukkan kemampuan siswa dalam menyelesaikan soal yaitu diperoleh rata-rata 7,14 . Siswa yang tuntas belajar sebanyak 17 siswa atau 47,22\% dan yang tidak tuntas sebanyak 19 siswa atau 52,78\%. Hal ini masih belum memenuhi kriteria yang diharapkan yaitu ketuntasan belajar klasikal harus mencapai prosentase $75 \%$. Sedangkan hasil evaluasi siswa pada siklus II diperoleh rata-rata 7,44; siswa yang tuntas belajar meningkat menjadi 26 siswa atau $76,22 \%$; siswa yang tidak tuntas sebanyak 10 orang siswa atau 10,78\%; dengah hasil ini berarti belum mencapai indikator yang telah diteapkan. Selanjutnya pada siklus III diperoleh skor rata-rata 8,84; siswa yang tuntas belajar meningkat lagi menjadi 36 siswa atau $100 \%$ dan tidak ada lagi siswa yang belum tuntas. Dengan hasil pada siklus III berarti sudah mencapai ketuntasan klassikal yang sudah sesuai dengan indikator, sehingga tidak perlu lagi melakukan tindakan berikutnya.

Sementara dari hasil pantauan keaktifan siswa dalam diskusi kelompok siperoleh hasil rata-sata sebagai berikut: pada siklus I diperoleh skor rata-rata 49,5\% dalam kategori "cukup"; pada siklus II diperoleh skor rata-rata 79,9\% dalam kategori "sedang"; dan pada siklus III diperoleh skor rata-rata 92,5\% dalam kategori .

Hasil angket tanggapan siswa menunjukkan bahwa kebanyakan siswa menyukai pendekatan pembelajaran kooperatif model Group Investigation (GI), dengan prosentase $83,14 \%$ atau "tinggi".

Hasil penelitian di atas sesuai dengan teori yang dikemukakan oleh Slameto (1991:180) bahwa dalam mempelajari suatu pelajaran siswa akan lebih memahami dan berhasil yang sesuai dengan harapan apabila dalam dirinya ada perasaan tertarik/berminat terhadap sesuatu yang dipelajari atau dihadapi.

Fauziah (2021) dalam jurnalnya juga menyatakan bahwa hasil belajar listening siswa kelas VIII/A SMP Negeri 4 Marabahan meningkat dengan menerapkan model Group Investigation.

Dengan demikian dapat dikatakan bahwa dalam pembelajaran dengan model pembelajaran kooperatif tipe Group Investigatian (GI) pada siswa kelas XI MIPA-1 semester gasal Sekolah Menengah Atas Negeri 1 Pemalang tahun pelajaran 2021/2022 dapat meningkatkan prestasi belajar siswa. sehingga pembelajaran dengan model pembelajaran kooperatif tipe Group Investigatian (GI) dapat menjadi solusi bagi guru untuk meningkatkan hasil belajar siswa.

\section{KESIMPULAN}

Dari hasil penelitian dan pembahasan dalam penerapan model pembelajaran Group Investigation (GI), dapat disimpulkan bahwa: 
1. Ada peningkatan prestasi belajar bahasa Inggirs siswa kelas XI MIPA-1, hal ini ditunjukkan dari hasil evaluasi pada siklus I, siklus II dan siklus II selalu mengalami peningkatan dan sampai mencapai indikator yang telah ditetapkan.

2. Ada peningkatan aktivitas siswa dan sudah memenuhi kriteria pada indikator, hal ini ditunjukkan aktivitas siswa pada siklus I, siklus II dan siklus III mengalami peningkatan..

3. Ada peningkatan kinerja/performance guru, hal ini ditunjukkan dari hasil pengamatan pada siklus I, siklus II dan siklus III yang selalu meningkat.

4. Respon siswa menunjukkan prosentase ketercapaian kelas dengan kategori pembelajaran menyenangkan.

\section{DAFTAR PUSTAKA}

Ali, Mohammad. (1984). Penelitian Kependidikan : Prosedur dan Strategi. Bandung: Angkasa Arifin, Zaenal. (1991). Evaluasi Instruksional. Bandung: PT Remaja Roesdakarya

Arikunto, Suharsimi dkk. (2015). Penelitian Tindakan kelas. Jakarta : PT Bumi Aksara

Arikunto, Suharsimi. (2006). Dasar-Dasar Evaluasi Pendidikan. Jakarta: Bumi Aksara (2006). Prosedur Penelitian Suatu Pendekatan Praktek. Jakarta: Rineka Cipta

Darsono, Max, dkk. (2000). Belajar dan Pembelajaran. Semarang: IKIP Semarang Press

Dimyati dan Mudjiono. (2002). Belajar dan Pembelajaran. Jakarta: Rineka Cipta

Fauziah, Herma. (2021). Penggunaan Model Group Investigation Untuk Meningkatkan Hasil Belajar Listening Siswa Kelas VIII/A SMP Negeri 4 Marabahan. Julak ( Jurnal Pembelajran \& Pendidik). Volume 1 No:1, September 2021.

Majid, A. M. (2018). Improving Students' Ability In Expressing Opinion Through Group Investigation At The Students Class XI IPA 1 Smester 1 SMA NEGERI 1 Abung Semuli Academic Year 2016-2017. Edukasi Lingua Sastra, 16(1), 110-117. https://doi.org/10.47637/elsa.v16i1.82

Muhtasim. (2020). Upaya Penerapan Metode Cooperative Learning Tipe Group Investigation Untuk Meningkatkan Hasil Belajar dan Ketrampilan Membaca Bahasa Inggris Siswa. Diunduh dari https://e-journal.undikma.ac.id/index.php/pedagogy/article/view/3049

Purwanto, Ngalim. (1992). Psikologi Pendidikan. Bandung: PT Remaja Rosakarya

Rusman. (2011). Model-model Pembelajaran, Mengembangkan Profesionalisme Guru. Jakarta: RajawaliPers.

Slameto. (1991). Belajar dan Faktor-Faktor Yang Mempengaruhinya Jakarta: Rineka Cipta

Sudjana, Nana. (2006). Penelitian Hasil Proses Belajar Mengajar. Bandung : PT Remaja Roesdakarya

Tim Penyusun KBBI. (2005). Kamus Besar Bahasa Indonesia. Semarang : Widya Karya

Tri Anni, Catharina. (2007). Psikologi Belajar. Semarang : UPT MKK UNNES 